\title{
PENGARUH KESADARAN PERPAJAKAN, SANKSI PAJAK, SIKAP FISKUS, TERHADAP KEPATUHAN WAJIB DI KPP PRATAMA LUBUK PAKAM
}

\author{
Jenita Halawa \\ Joana L. Saragih
}

\begin{abstract}
Abstrak
Penelitian bertujuan untuk mengetahui pengaruh kesadaran perpajakan, sanksi pajak dan sikap fiskus terhadap kepatuhan wajib pajak orang pribadi pada KPP Pratama Lubuk Pakam. Untuk itu dirumuskan masalah penelitian, yaitu "Apakah kesadaran perpajakan, sanksi pajak, dan sikap fiskus mempunyai pengaruh yang signifikan secara parsial maupun simultan terhadap kepatuhan wajib pajak orang pribadi pada KPP Pratama Lubuk Pakam?". Hipotesis yang dikemukakan adalah "kesadaran perpajakan, sanksi pajak, dan sikap fiskus mempunyai pengaruh yang signifikan secara parsial maupun simultan terhadap kepatuhan wajib pajak orang pribadi pada KPP Pratama Lubuk Pakam.

Teknik pengambilan sampel yang digunakan adalah convenience sampling dengan jumlah sampel sebanyak 100 responden. Data diperoleh dari hasil kuesioner yang diisikan kepada para responden di KPP Pratama Lubuk Pakam tahun 2015. Teknik analisis data yang digunakan adalah regresi linier berganda dan pengujian hipotesis menggunakan uji $\mathrm{t}$ dan uji $\mathrm{F}$ dengan tingkat signifikansi sebesar $5 \%$.

Hasil uji secara parsial (uji t) menunjukkan bahwa kesadaran perpajakan mempunyai pengaruh positif dan signifikan terhadap kepatuhan wajib pajak, sanksi pajak mempunyai pengaruh positif dan signifikan terhadap kepatuhan wajib pajak, dan sikap fiskus mempunyai pengaruh positif dan signifikan terhadap kepatuhan wajib pajak. Hasil uji secara simultan (uji F) menunjukkan bahwa variabel kesadaran perpajakan, sanksi pajak, dan sikap fiskus mempunyai pengaruh signifikan terhadap kepatuhan wajib pajak.

Penelitian ini bertujuan untuk mengetahui pengaruh kesadaran perpajakan, sanksi pajak dan sikap fiskus terhadap kepatuhan wajib pajak orang pribadi pada KPP Pratama Lubuk Pakam. Untuk itu dirumuskan masalah penelitian, yaitu "Apakah kesadaran perpajakan, sanksi pajak, dan sikap fiskus mempunyai pengaruh yang signifikan secara parsial maupun simultan terhadap kepatuhan wajib pajak orang pribadi pada KPP Pratama Lubuk Pakam?". Hipotesis yang dikemukakan adalah "kesadaran perpajakan, sanksi pajak, dan sikap fiskus mempunyai pengaruh yang signifikan secara parsial maupun simultan terhadap kepatuhan wajib pajak orang pribadi pada KPP Pratama Lubuk Pakam.
\end{abstract}

Kata kunci : Kepatuhan Wajib Pajak, Kesadaran Perpajakan, Sanksi Pajak, dan Sikap Fiskus 


\section{PENDAHULUAN}

\section{Latar Belakang}

Dewasa ini pajak merupakan suatu hal yang wajib untuk dipahami dengan baik, itu terjadi karena pajak sudah menjadi bagian penting dalam perekonomian. Siapapun terutama wajib pajak pasti akan berurusan dengan pajak, kendati pajak merupakan hal yang terpenting dalam perekonomian, namun tidak sedikit masyarakat kesulitan dalam menetapkan pajak. Hal itu disebabkan masih banyak masyarakat yang tidak mengetahui dengan baik sehingga kurang memahami tentang pajak. Bagi masyarakat pada umumnya pajak merupakan hal yang mengalami masalah dalam upayanya melaporkan serta membayar kewajiban pajaknya.

Pajak menurut pasal 1 Undang-undang Nomor 28 Tahun 2007 tentang Ketentuan Umum dan Tata Cara Perpajakan, Pajak adalah kontribusi wajib kepada Negara yang terutang oleh orang pribadi atau badan yang bersifat memaksa berdasarkan Undang-undang, dengan tidak mendapat jasa timbal balik secara langsung dan digunakan untuk keperluan Negara bagi sebenar-benarnya kemakmuran rakyat.

Perkembangan ekonomi dan teknologi semakin pesat membutuhkan dana yang tidak sedikit. Dana yang telah ada dipergunakan Pemerintah untuk membangun fasilitas-fasilitas sosial seperti jalan raya, jembatan, rumah sakit, dan lain-lain. Dalam kondisi yang sekarang ini diperlukan dana yang banyak serta adanya cara pengelolaan dana yang baik. Hal itu disebabkan banyak fasilitas-fasilitas sosial yang tidak layak lagi untuk digunakan, sehingga diperlukan dana yang banyak untuk memperbaiki fasilitas tersebut.

Begitu besarnya peran pajak dalam APBN, maka usaha untuk meningkatkan penerimaan pajak terus dilakukan oleh pemerintah yang dalam hal ini merupakan tugas Direktorat Jenderal Pajak. Berbagai upaya dilakukan Direktorat Jenderal Pajak agar penerimaan pajak maksimal, antara lain adalah dengan ekstensifikasi dan intensifikasi pajak. Hal tersebut dilakukan dengan cara perluasan subjek dan objek pajak, dengan menjaring wajib pajak baru.

Salah satu kendala yang dapat menghambat keefektifan pengumpulan pajak adalah kepatuhan wajib pajak (tax compliance). Kepatuhan wajib pajak dapat didefinisikan sebagai suatu sikap atau perilaku seorang wajib pajak yang melaksanakan semua kewajiban perpajakannya dan menikmati semua hak perpajakannya sesuai dengan ketentuan peraturan perundangan yang berlaku. Kepatuhan yang dimaksudkan merupakan istilah tingkat sampai dimana wajib pajak mematuhi undang-undang perpajakan. Misalnya jika wajib pajak membayar dan melaporkan pajak terutangnya tepat waktu, maka wajib pajak dianggap patuh. Oleh karena itu kepatuhan wajib pajak merupakan faktor utama yang mempengaruhi realisasi penerimaan pajak.

Wajib Pajak orang pribadi atau badan meliputi pembayar pajak, pemotong pajak dan pemungut pajak yang mempunyai hak dan kewajiban perpajakan 
sesuai dengan ketentuan peraturan perundang-undangan perpajakan (UndangUndang Nomor 16 Tahun 2009 tentang tentang Ketentuan Umum Perpajakan). Wajib pajak menurut Mardiasmo (2013) adalah sekumpulan orang pribadi atau badan meliputi pembayaran pajak, pemotongan pajak, dan pemungut pajak, yang mempunyai hak dan kewajiban perpajakan sesuai dengan ketentuan peraturan perundang-undangan perpajakan.

Dari ketentuan diatas menyebutkan bahwa ukuran tingkat kepatuhan wajib pajak paling utama diketahui apakah wajib pajak telah menyampaikan SPT-nya atau belum, baik itu SPT Tahunan atau SPT Masa. Rasio Kepatuhan Pelaporan SPT Tahunan Wajib Pajak Orang Pribadi pada KPP Pratama Lubuk Pakam tahun 2014 dapat dilihat pada tabel berikut:

Tabel 1

Kepatuhan Pelaporan SPT Tahunan Wajib Pajak Orang Pribadi pada KPP Pratama Lubuk Pakam tahun 2011-2014

\begin{tabular}{|c|c|c|c|c|c|c|}
\hline \multirow{2}{*}{ TAHUN } & \multirow{2}{*}{$\begin{array}{l}\text { Total Seluruh } \\
\text { WP Terdaftar } \\
\text { di Data Base } \\
\text { (termasuk WP } \\
\text { NE, DE, PL) }\end{array}$} & \multicolumn{2}{|c|}{$\begin{array}{c}\text { SPT YANG } \\
\text { DILAPORKAN }\end{array}$} & \multicolumn{2}{|c|}{$\begin{array}{c}\text { SPT YANG } \\
\text { BELUM } \\
\text { DILAPORKAN }\end{array}$} & \multirow{2}{*}{$\begin{array}{c}\text { JUMLAH } \\
\text { WPOP } \\
\text { WAJIB } \\
\text { SPT }\end{array}$} \\
\hline & & JUMLAH & $\%$ & JUMLAH & $\%$ & \\
\hline 2011 & 126.200 & 33.773 & 44,9 & 41.432 & 55,1 & 75.205 \\
\hline 2012 & 141.030 & 37.049 & 41,15 & 52.986 & 58,85 & 90.035 \\
\hline 2013 & 153.900 & 44.556 & 43,3 & 58.349 & 56,7 & 102.905 \\
\hline 2014 & 168.815 & 40.550 & 34,42 & 77.269 & 65,58 & 117.819 \\
\hline
\end{tabular}

Sumber : KPP Pratama Lubuk Pakam Tahun 2014

Berdasarkan Tabel 1 pada periode 2012 persentase SPT yang dilaporkan mengalami penurunan dari tahun 2011 yaitu dari 44,9\% menjadi $41,15 \%$. Sedangkan pada periode 2013, persentase SPT yang dilaporkan mengalami peningkatan dari tahun 2012 yaitu dari 41,15\% menjadi 43,3\%. Peningkatan persentase tersebut juga diimbangi dengan peningkatan jumlah wajib pajak orang pribadi. Pada periode 2014, persentase SPT yang dilaporkan mengalami penurunan dari tahun 2013 yaitu dari 43,3 \% menjadi 34,42\%.

Berdasarkan data yang didapat pada Kantor Pelayanan Pajak Pratama Lubuk Pakam, jumlah wajib pajak orang pribadi terus bertambah setiap tahunnya, namun yang menjadi masalah adalah jumlah wajib pajak yang tidak menyampaikan SPT pun ikut terus bertambah setiap tahunnya. Persentase jumlah wajib pajak orang pribadi yang tidak patuh pada KPP Pratama Lubuk Pakam terus meningkat, dan dengan terus meningkatnya jumlah wajib pajak yang tidak patuh setiap tahunnya menunjukan bahwa masih banyak wajib pajak orang pribadi yang sebenarnya berpotensial untuk meningkatkan pendapatan pajak negara apabila wajib pajak tersebut patuh memenuhi kewajiban perpajakannya 
Beberapa fenomena kasus-kasus yang terjadi dalam dunia perpajakan Indonesia belakangan ini membuat masyarakat dan wajib pajak khawatir untuk membayar pajak. Kondisi tersebut dapat mempengaruhi kepatuhan wajib pajak karena para wajib pajak tidak ingin pajak yang telah dibayarkan disalahgunakan oleh aparat pajak itu sendiri. Oleh karena itu, beberapa masyarakat dan wajib pajak berusaha menghindari pajak.

Peran serta masyarakat wajib pajak dalam memenuhi kewajiban membayar pajak berdasarkan ketentuan perpajakan sangat diharapkan, sehingga kepatuhan wajib pajak dalam membayar pajak merupakan strategi dalam peningkatan penerimaan pajak. Untuk mengukur perilaku wajib pajak, yaitu seberapa besar tingkat kepatuhan wajib pajak dalam melaksanakan kewajiban mengisi dan menyampaikan Surat Pemberitahuan (SPT) secara benar dan tepat semakin tinggi pula tingkat kepatuhan wajib pajak dalam melaksanakan dan memenuhi kewajibannya.

Adapun tujuan dari penelitian ini adalah untuk mengetahui "apakah kesadaran perpajakan, sanksi pajak, dan sikap fiskus mempunyai pengaruh yang signifikan secara parsial maupun simultan terhadap kepatuhan wajib pajak orang pribadi di KPP Pratama Lubuk Pakam"

\section{B. TINJAUAN PUSTAKA}

1. Kepatuhan Wajib Pajak

Kepatuhan Wajib Pajak merupakan pemenuhan kewajiban perpajakan yang dilakukan oleh pembayar pajak dalam rangka memberikan kontribusi bagi pembangunan Negara yang diharapkan didalam pemenuhannya dilakukan secara sukarela.

\section{Kesadaran Perpajakan}

Kesadaran membayar pajak menurut Widayati dan Nurlis (2010) merupakan unsur dalam manusia dalam memahami realitas dan bagaimana cara bertindak atau menyikapi terhadap realitas untuk patuh membayar pajak kepada kas negara untuk kepentingan bersama. Kesadaran yang dimiliki oleh manusia meliputi kesadaran dalam diri, akan diri sesama, masa silam, dan kemungkinan masa depannya.

\section{Sanksi Pajak}

Sanksi pajak merupakan jaminan bahwa ketentuan peraturan perundangundangan perpajakan (norma perpajakan) akan dituruti/ditaati/dipatuhi, dengan kata lain sanksi perpajakan merupakan alat pencegah agar wajib pajak tidak melanggar norma perpajakan, Mardiasmo (2006).

\section{Sikap Fiskus}

Sikap fiskus dapat diartikan sebagai cara petugas pajak dalam membantu mengurus atau menyiapkan segala keperluan yang dibutuhkan seseorang (dalam hal ini adalah wajib pajak) .

Pelayanan yang diberikan oleh fiskus selama proses perpajakan berkaitan dengan sikap wajib pajak. Proses perpajakan melibatkan fiskus dan 
wajib pajak membuat pelayanan yang diberikan oleh fiskus turut membentuk sikap (atitude) wajib pajak dalam mengikuti proses perpajakan. Semakin baik pelayanan fiskus, maka wajib pajak akan memiliki sikap yang positif terhadap proses perpajakan, Nugroho (2012). Pengungkapan Wajib (mandatory disclosure)

\section{Wajib Pajak Orang Pribadi}

Wajib pajak merupakan orang pribadi atau badan, meliputi pembayaran pajak, pemotongan pajak, yang mempunyai hak dan kewajiban perpajakan sesuai dengan ketentuan dan peraturan perundang-undangan perpajakan, Irianto (2011). Wajib pajak adalah orang pribadi atau badan yang menurut ketentuan peraturan perundang-undangan perpajakan ditentukan untuk melakukan kewajiban perpajakan, termasuk pemungutan pajak atau pemotong pajak tertentu. Wajib pajak bisa berupa wajib pajak orang pribadi atau wajib pajak badan. Wajib pajak pribadi adalah setiap orang pribadi yang memiliki penghasilan diatas pendapatan tidak kena pajak, Rahman (2010).

\section{Pengaruh Kesadaran Perpajakan terhadap Kepatuhan Wajib Pajak}

Kesadaran perpajakan menyatakan bahwa penilaian positif masyarakat wajib pajak terhadap pelaksanaan fungsi negara oleh pemerintah akan menggerakan masyarakat untuk mematuhi kewajiban untuk membayar pajak. Suyatmin (2004) menyatakan bahwa secara empiris juga telah dibuktikan bahwa makin tinggi kesadaran perpajakan wajib pajak maka makin tinggi tingkat kepatuhan wajib pajak. Kesadaran wajib pajak sangat diperlukan guna meningkatkan kepatuhan pajak.

Seseorang dikatakan memiliki kesadaran pajak antara lain apabila mengetahui adanya UU dan ketentuan perpajakan dan mau mematuhinya, mengetahui fungsi pajak untuk menyejahterakan rakyat, menghitung, membayar, melaporkan pajak tepat waktu dan secara sukarela tanpa paksaan.

Penelitian ini diperkuat oleh Tryana A.M Tiraada (2013) menemukan bahwa kesadaran perpajakan memiliki pengaruh positif signifikan pada kepatuhan wajib pajak, jika kesadaran wajib pajak baik maka kepatuhan wajib pajak pun akan naik. Sikap sadar wajib pajak akan kewajiban perpajakannya dan sadar akan fungsi pajak akan mempengaruhi kepatuhan wajib pajak sehingga kepatuhan pajaknya dapat meningkat. Maka, semakin tinggi kesadaran perpajakan maka akan meningkatkan kepatuhan wajib pajak.

\section{Pengaruh Sanksi Pajak terhadap Kepatuhan Wajib Pajak}

Menurut Suyatmin (2004) menyatakan bahwa agar undang- undang dan peraturan dipatuhi, maka harus ada sanksi bagi pelanggarnya, demikiannya untuk hukum pajak. Wajib pajak akan memenuhi kewajiban perpajakan apabila memandang sanksi perpajakan akan lebih banyak merugikannya. Semakin banyak sisa tunggakan pajak yang harus dibayar wajib pajak, maka akan semakin berat bagi wajib pajak untuk melunasinya, dan keterlambatan dalam 
melunasinya akan dikenai denda. Oleh sebab itu sikap atau pandangan wajib pajak terhadap sanksi pajak seperti nilai kewajaran denda bunga, keadilan dalam pelaksanaan dan perhitungannya diduga akan berpengaruh terhadap tingkat kepatuhan wajib pajak dalam membayar pajak.

Didukung juga dengan hasil penelitian yang dilakukan Thia Dwi Utami (2011) menyebutkan sanksi pajak berpengaruh positif signifikan terhadap kepatuhan wajib pajak orang pribadi. Jurnal John Hutagaol (2007), penerapan sanksi perpajakan baik administrasi (denda, bunga dan kenaikan) dan pidana (kurungan atau penjara) mendorong kepatuhan wajib pajak.

\section{Pengaruh Sikap Fiskus terhadap Kepatuhan Wajib Pajak}

Kepatuhan wajib pajak dalam memenuhi kewajiban membayar pajak tergantung pada bagaimana sikap petugas pajak (fiskus) memberikan mutu pelayanan yang terbaik kepada wajib pajak Jatmiko (2006). Fiskus diharapkan memiliki kompetensi berupa keahlian (skill), pengetahuan (knowledge), dan pengalaman (experience) dalam hal kebijakan perpajakan, administrasi pajak dan perundang-undangan perpajakan. Selain itu fiskus harus memiliki motivasi yang tinggi sebagai pelayan publik. Kepatuhan wajib pajak akan lebih meningkat apabila fiskus bersikap kooperatif, adil, jujur, memberikan informasi serta kemudahan, sehingga tidak mengecewakan wajib pajak.

Hal ini diperkuat dengan hasil penelitian Jatmiko (2006) mengungkapkan bahwa sikap fiskus berpengaruh positif dan signifikan terhadap kepatuhan wajib pajak. Semakin baik sikap fiskus maka semakin tinggi pula kepatuhan wajib pajak.

\section{Kerangka Berpikir}

\section{Gambar 1. Kerangka Berpikir}

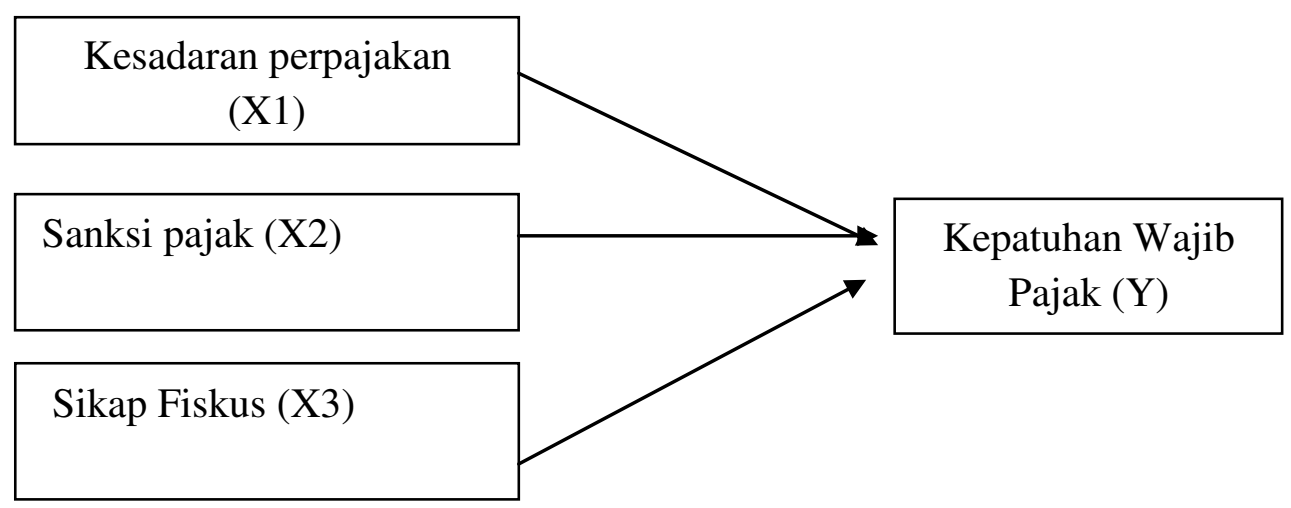




\section{Hipotesis}

Hipotesis penelitian ini adalah kesadaran perpajakan, sanksi pajak, dan sikap fiskus mempunyai pengaruh yang signifikan terhadap kepatuhan wajib pajak orang pribadi pada KPP Pratama Lubuk Pakam.

\section{PEMBAHASAN}

1 Analisis Deskriptif

Tabel 2 Statistik Deskriptif

\begin{tabular}{|l|r|r|r|r|r|}
\hline & N & \multicolumn{1}{|c|}{ Minimum } & Maximum & Mean & \multicolumn{1}{c|}{ Std. Deviation } \\
\hline Kepatuhan (Y) & 100 & 5 & 20 & 16,62 & 3,162 \\
Kes Perpajakan (X1) & 100 & 5 & 20 & 14,72 & 2,878 \\
Sanksi Pajak (X2) & 100 & 6 & 20 & 13,85 & 3,016 \\
Sikap Fiskus (X3) & 100 & 4 & 20 & 17,14 & 2,923 \\
Valid N (listwise) & 100 & & & & \\
\hline
\end{tabular}

Sumber : hasil output SPSS 19 (data diolah)

Berdasarkan tabel 2 menunjukkan jumlah responden (N) sebanyak 100.

Kesadaran Perpajakan memiliki nilai rata-rata sebesar 14,72 dan nilai deviasi standar sebesar 2,878. Nilai terendah sebesar 5 dan nilai tertinggi sebesar 20 . Sanksi Pajak memiliki nilai rata-rata sebesar 13,85 dan nilai deviasi standar sebesar 30,16. Nilai terendah sebesar 6 dan nilai tertinggi sebesar 20. Sikap Fiskus memiliki nilai rata-rata sebesar 17,14 dan nilai deviasi standar sebesar 2,923. Nilai terendah sebesar 4 dan nilai tertinggi sebesar 20. Kepatuhan Wajib Pajak memiliki nilai rata-rata sebesar 16,62 dan nilai deviasi standar sebesar 3,162 . Nilai terendah sebesar 5 dan nilai tertinggi sebesar 20 .

Hal tersebut menunjukkan bahwa kualitas data dalam penelitian ini memberikan hasil yang cukup baik karena nilai mean lebih besar dari nilai standar deviasi yang mengindikasikan bahwa standar error dari setiap variabelnya kecil.

\section{Uji Validitas dan Reliabilitas}

Tabel 3. Uji Validitas

\begin{tabular}{|c|c|c|c|}
\hline Variabel & Item & $\begin{array}{c}\text { Corrected Item-Total } \\
\text { Correlation }\end{array}$ & Ket. \\
\hline Kesadaran Perpajakan (X1) & X1 & 0,675 & Valid \\
\hline Sanksi Pajak (X2) & X2 & 0,557 & Valid \\
\hline Sikap Fiskus (X3) & X3 & 0,650 & Valid \\
\hline Kepatuhan Wajib Pajak (Y) & Y1 & 0,737 & Valid \\
\hline
\end{tabular}

Sumber: Pengolahan Data SPSS IBM 19 
Tabel 4. Tabel Uji Reliabilitas

\begin{tabular}{|l|c|l|}
\hline \multicolumn{1}{|c|}{ Variabel } & Cronbach Alpha & Keterangan \\
\hline Kesadaran Perpajakan (X1) & 0,773 & Reliabel \\
\hline Sanksi Pajak (X2) & 0,825 & Reliabel \\
\hline Sikap Fiskus (X3) & 0,783 & Reliabel \\
\hline Kepatuhan Wajib Pajak (Y) & 0,742 & Reliabel \\
\hline
\end{tabular}

Sumber: Pengolahan Data SPSS IBM 19

Berdasarkan tabel 3 hasil uji validitas di atas, disimpulkan bahwa seluruh item pertanyaan yang digunakan dalam penelitian ini adalah valid, hal ini bisa dilihat dari nilai masing-masing item pertanyaan memiliki nilai Corrected ItemTotal Correlation yang lebih besar dari 0,50 .

Berdasarkan tabel 4 hasil uji reliabilitas di atas, maka dapat disimpulkan variabel-variabel yang digunakan dalam penelitian ini telah reliabel karena keseluruhan variabel memiliki nilai Cronbach's Alpha yang lebih besar dari 0,60 sehingga layak digunakan untuk menjadi alat ukur instrumen kuesioner dalam penelitian ini.

\section{Pengujian Asumsi Klasik}

3.1 Uji Normalitas Data

\section{Gambar 2. Histogram}

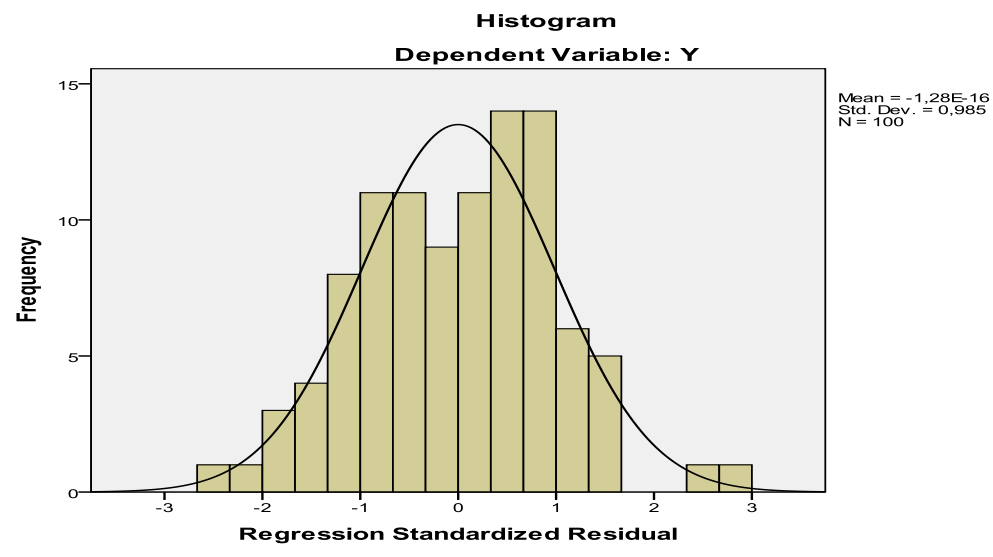


Gambar 3. P-Plot

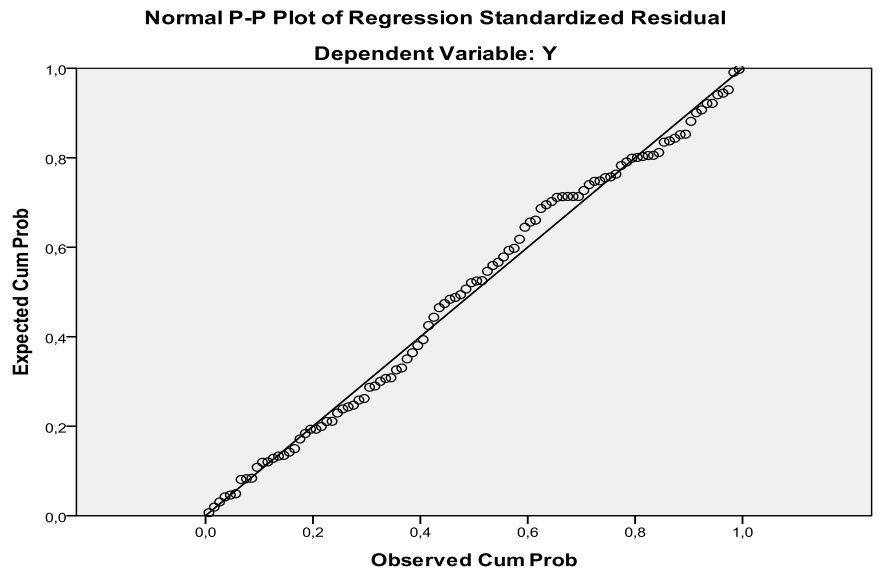

Dari gambar 2 dan 3 diatas dapat diketahui bahwa :

1. Output Histogram Standardized residual terlihat bahwa kurva dependent dan regression Standardized residual membentuk gambar seperti lonceng. Oleh karena itu berdasarkan uji normalitas, analisis regresi layak di gunakan.

2. Output PP Plot Standardized residual terlihat bahwa sebarannya mengikuti pola linier dan terlihat bahwa titik-titik menyebar di sekitar garis diagonal. maka data terdistribusi dengan normal sehingga dapat dikatakan model regresi data telah memenuhi asumsi normalitas.

\subsection{Hasil Uji Multikolonieritas}

Tabel 5. Uji Multikolinearitas

Coefficients $^{\mathrm{a}}$

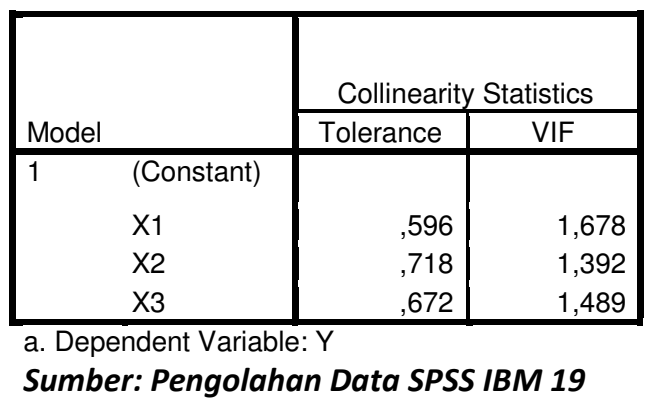

Dari tabel 5 terlihat bahwa tidak ada variabel bebas yang memiliki nilai tolerance kurang dari 0,10 . Hasil uji VIF juga menunjukan hal yang sama yaitu tidak ada satupun variabel independen yang memiliki VIF lebih dari 10. Jadi dapat disimpulkan bahwa tidak ada multikolinieritas antar variabel independen dalam model regresi atau uji multikolinieriatas sudah terpenuhi. 


\subsection{Hasil Uji Heterokedastisitas}

\section{Gambar 4. Uji Heterokeastisitas}

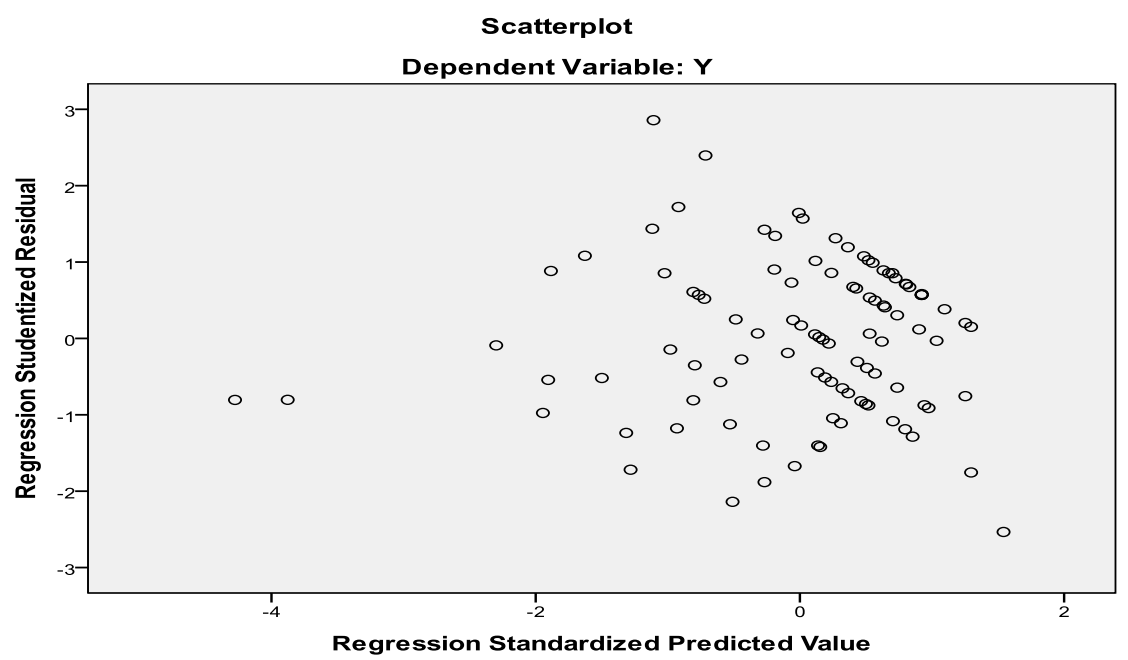

Berdasarkan gambar 5 di atas, dapat diketahui bahwa data (titik-titik) menyebar secara merata di atas dan di bawah garis nol, tidak berkumpul di satu tempat, serta tidak membentuk pola tertentu sehingga dapat disimpulkan bahwa uji regresi ini tidak terjadi masalah heteroskedastisitas.

\section{Hasil Pengujian Hipotesis}

\subsection{Uji t (Parsial)}

Tabel 6 Hasil Uji Secara Parsial (Uji t)

\begin{tabular}{|c|c|c|c|c|c|c|}
\hline \multirow{2}{*}{\multicolumn{2}{|c|}{ Model }} & \multicolumn{2}{|c|}{ Unstandardized Coefficients } & \multirow{2}{*}{$\begin{array}{c}\text { Standardized } \\
\text { Coefficients } \\
\text { Beta }\end{array}$} & \multirow[b]{2}{*}{$t$} & \multirow[b]{2}{*}{ Sig. } \\
\hline & & $\mathrm{B}$ & Std. Error & & & \\
\hline & (Constant) & 1,279 & 1,410 & & ,907 & ,367 \\
\hline & $\mathrm{X} 1$ & ,295 & ,096 & ,268 & 3,055 & ,003 \\
\hline & $\mathrm{X} 2$ & ,219 & ,084 & ,209 & 2,609 & 011 \\
\hline & X3 & ,465 & ,089 & ,430 & 5,197 & ,000 \\
\hline
\end{tabular}

Berdasarkan hasil uji secara parsial pada Tabel 6, untuk variabel kesadaran perpajakan diperoleh koefisien regresi dengan arah positif sebesar 0,295. Hal ini berarti bahwa pengaruh antara variabel kesadaran perpajakan dengan variabel kepatuhan wajib pajak adalah positif. kesadaran perpajakan memiliki nilai sig. sebesar 0,003 dimana $0,003<0,05$ dan nilai $t_{\text {hitung }} 3,055>t_{\text {tabel }} 1,985$, sehinggga Ho ditolak dan H1 diterima. Dengan demikian, dapat diambil kesimpulan bahwa variabel kesadaran perpajakan mempunyai pengaruh positif dan signifikan terhadap kepatuhan wajib pajak pada KPP Pratama Lubuk Pakam. 
Berdasarkan hasil uji secara parsial pada Tabel 6, untuk variabel sanksi pajak diperoleh koefisien regresi dengan arah positif sebesar 0,219. Hal ini berarti bahwa pengaruh antara variabel sanksi pajak dengan variabel kepatuhan wajib pajak adalah positif. sanksi pajak memiliki nilai sig. sebesar 0,011 dimana 0,011 $<0,05$ dan nilai $t_{\text {hitung }} 2,609>t_{\text {tabel }} 1,985$, sehinggga Ho ditolak dan $\mathrm{H} 2$ diterima. Dengan demikian, dapat diambil kesimpulan bahwa variabel sanksi pajak mempunyai pengaruh positif dan signifikan terhadap kepatuhan wajib pajak pada KPP Pratama Lubuk Pakam.

Berdasarkan hasil uji secara parsial pada Tabel 6, untuk variabel sikap fiskus diperoleh koefisien regresi dengan arah positif sebesar 0,465. Hal ini berarti bahwa pengaruh antara variabel sikap fiskus dengan variabel kepatuhan wajib pajak adalah positif. sikap fiskus memiliki nilai sig. sebesar 0,000 dimana 0,000 $<0,05$ dan nilai $t_{\text {hitung }} 5,197>t_{\text {tabel }} 1,985$, sehinggga Ho ditolak dan H3 diterima. Dengan demikian, dapat diambil kesimpulan bahwa variabel sikap fiskus mempunyai pengaruh positif dan signifikan terhadap kepatuhan wajib pajak pada KPP Pratama Lubuk Pakam.

\subsection{Uji F (simultan)}

Tabel 7. Hasil Uji F

\begin{tabular}{|ll|r|r|r|r|r|}
\hline Model & & Sum of Squares & df & Mean Square & F & Sig. \\
\hline 1 & Regression & 552,760 & 3 & 184,253 & 40,495 &, $000^{\mathrm{a}}$ \\
& Residual & 436,800 & 96 & 4,550 & & \\
& Total & 989,560 & 99 & & & \\
\hline
\end{tabular}

a. Predictors: (Constant), X3, X2, X1

b. Dependent Variable: $Y$

Sumber: Pengolahan Data SPSS IBM 19

Berdasarkan Tabel 7 menunjukkan bahwa nilai sig dari model penelitian ini adalah sebesar 0,000 dimana nilai 0,000 $<0,05$ dan $F_{\text {hitung }} 40,495>F_{\text {tabel }} 2,699$ Berdasarkan hasil tersebut maka dapat disimpulkan bahwa $\mathrm{H} 4$ diterima dan Ho ditolak. Hal ini menunjukkan bahwa terdapat hubungan antara variabel independen dengan variabel dependen. Artinya kesadaran perpajakan, sanksi pajak dan sikap fiskus secara bersama-sama mempunyai pengaruh signifikan terhadap kepatuhan wajib pajak pada KPP Pratama Lubuk Pakam.

\section{Pembahasan}

Berdasarkan hasil uji secara parsial pada Tabel 6, untuk variabel kesadaran perpajakan diperoleh koefisien regresi variabel dengan arah positif sebesar 0,295. kesadaran perpajakan memiliki nilai sig. sebesar 0,003 dimana 0,003 $<0,05$ dan nilai $\mathrm{t}_{\text {hitung }} 3,055>\mathrm{t}_{\text {tabel }} 1,985$, sehinggga Ho ditolak dan H1 diterima. Dari 
penjelasan tersebut dapat disimpulkan bahwa variabel kesadaran perpajakan mempunyai pengaruh positif dan signifikan terhadap kepatuhan wajib pajak.

Hasil uji secara parsial pada Tabel 6, untuk variabel sanksi pajak diperoleh koefisien regresi variabel dengan arah positif sebesar 0,219. Sanksi pajak memiliki nilai sig. sebesar 0,011 dimana $0,011<0,05$ dan nilai $t_{\text {hitung }} 2,609>t_{\text {tabel }}$ 1,985, sehinggga Ho ditolak dan H2 diterima. Dengan demikian, dapat diambil kesimpulan bahwa variabel sanksi pajak mempunyai pengaruh positif dan signifikan terhadap kepatuhan wajib pajak.

Hasil uji secara parsial pada Tabel 6, untuk variabel sikap fiskus diperoleh koefisien regresi variabel dengan arah positif sebesar 0,465. sikap fiskus memiliki nilai sig. sebesar 0,000 dimana $0,000<0,05$ dan nilai $t_{\text {hitung }} 5,197>t_{\text {tabel }}$ 1,985, sehinggga Ho ditolak dan Ha4 diterima. Dengan demikian, dapat diambil kesimpulan bahwa variabel sikap fiskus mempunyai pengaruh positif dan signifikan terhadap kepatuhan wajib pajak.

\section{KESIMPULAN DAN SARAN}

\subsection{Kesimpulan}

1. Berdasarkan hasil pengujian hipotesis untuk variabel kesadaran perpajakan, diperoleh koefisien regresi dengan arah positif 0,295 dan nilai sig. sebesar 0,003 dimana $0,003<0,05$ dan nilai $t_{\text {hitung }} 3,055>t_{\text {tabel }} 1,985$. Hal tersebut menunjukkan bahwa secara parsial variabel kesadaran perpajakan mempunyai pengaruh positif dan signifikan terhadap variabel kepatuhan wajib pajak.

2. Berdasarkan hasil pengujian hipotesis untuk variabel sanksi pajak, diperoleh koefisien regresi dengan arah positif 0,219. dan nilai sig. sebesar 0,011 dimana $0,011<0,05$ dan nilai $t_{\text {hitung }} 2,609>\mathrm{t}_{\text {tabel }} 1,985$. Hal tersebut menunjukkan bahwa secara parsial variabel sanksi pajak mempunyai pengaruh positif dan signifikan terhadap variabel kepatuhan wajib pajak.

3. Berdasarkan hasil pengujian hipotesis untuk variabel sikap fiskus, diperoleh koefisien regresi dengan arah positif 0,465 . dan nilai sig. sebesar 0,000 dimana $0,000<0,05$ dan nilai $t_{\text {hitung }} 5,197>\mathrm{t}_{\text {tabel }} 1,985$. Hal tersebut menunjukkan bahwa secara parsial variabel sikap fiskus mempunyai pengaruh positif dan signifikan terhadap variabel kepatuhan wajib pajak.

4. Berdasarkan uji $F$ diperoleh nilai sig sebesar 0,000 dimana nilai $0,000<0,05$ dan $\mathrm{F}_{\text {hitung }} 40,495>\mathrm{F}_{\text {tabel }} 2,699$. Hal tersebut menunjukkan variabel kesadaran perpajakan, sanksi pajak dan sikap fiskus secara simultan mempunyai pengaruh positif dan signifikan terhadap kepatuhan wajib pajak.

\subsection{Saran}

Berdasarkan kesimpulan di atas maka penulis akan memberikan saran sebagai berikut:

1. Fiskus harus bertindak profesional dan memiliki mental yang siap melayani wajib pajak dengan sebaik-baiknya. Pihak Direktorat Jenderal Pajak 
dapat melakukan pelatihan pelayanan wajib pajak agar dapat meningkatkan pelayanan fiskus bagi wajib pajak. Fiskus juga diseleksi dengan ketat sesuai dengan bidang keahlian yang dibutuhkan agar fiskus benar-benar cakap dalam melakukan tugasnya.

2. Perlu lebih di galakkan tindakan penyidikan terhadap wajib pajak tidak patuh membayar serta melaporkan SPT sehingga sanksi yang di berikan dapat benar-benar di jalankan serta di terapkan terhadap wajib pajak tidak taat, sebab hal ini juga menunjang kredibilitas Dirjen Pajak dalam mengambil tindakan serta menjalankan tugas sesuai dengan aturan perpajakan.

3. Bagi Peneliti selanjutnya disarankan untuk melakukan penelitian yang sama, dengan menambah variabel, populasi dan sampel yang berbeda agar diperoleh kesimpulan yang mendukung dan memperkuat teori dan konsep yang telah dibangun sebelumnya baik oleh peneliti maupun oleh penelitipeneliti terdahulu.

\section{DAFTAR PUSTAKA}

Ghozali, Imam. 2005. Aplikasi Analisis Multivariate dengan Program SPSS. Edisi Ketiga. Semarang: Badan Penerbit UNDIP.

Irianto, S. E. 2005. Politik Perpajakan: Membangun Demokrasi Negara. Yogyakarta: UII Press.

Jatmiko, Agus Nugroho. 2006. Pengaruh Sikap Wajib Pajak Pada Pelaksanaan Sanksi Denda, Pelayanan Fiskus dan Kesadaran Perpajakan Terhadap Kepatuhan Wajib Pajak. Tesis. Semarang : Program Studi Magister Akuntansi Universitas Diponegoro.

John Hutagaol, Wing Wahyu Winarno, Arya Pradipta. 2006. Strategi Meningkatkan Kepatuhan Wajib Pajak. Jurnal Akuntabilitas. Vol.6 No.2. ISSN 1412-0240

Kamus Besar Bahasa Indonesia Edisi Ketiga. 2007. Jakarta: Balai Pustaka. Mardiasmo. 2006. Perpajakan. Yogyakarta: Cv Andi

Muliari, N.K, dan Putu Ery Setiawan, 2011. Pengaruh Persepsi Tentang Sanksi Perpajakan dan Kesadaran Wajib Pajak Pada Kepatuhan Pelaporan Wajib Pajak Orang Pribadi di Kantor Pelayanan Pajak Pratama Denpasar Timur. Jurnal Ilmiah Akuntansi dan Bisnis Vol.6, No.1 Januari 2011. 1-23

Muljono, Djoko. 2007. Undang-Undang Republik Indonesia Nomor 28 Tahun 2007 tentang Ketentuan Umum dan Tata Cara Perpajakan:Jakarta

Republik Indonesia, Peraturan Menteri Keuangan No. 192/PMK.03/2007 Tentang Tata Cara Penetapan Wajib pajak Dengan Kriteria Tertentu. Jakarta Resmi. 2009. Perpajakan : Teori dan Kasus. Salemba Empat. Jakarta

Rahayu, Siti Kurnia. 2010. Perpajakan Indonesia Konsep \& Aspek Formal. Yogyakarta: Graha Ilmu 
Tryana A.M. Tiraada. 2013. Kesadaran Perpajakan, Sanksi Pajak, Sikap Fiskus Terhadap Kepatuhan Wajib Pajak Orang Pribadi di Kabupaten Minahasa Selatan. Universitas Sam Ratulangi Manado. ISSN 2303-1174

Undang-Undang Republik Indonesia No. 16. 2009. Tentang Ketentuan Umum dan Tata Cara Perpajakan (KUP) sebagaimana telah diubah terakhir. Jakarta.

Utami, Thia Dwi. 2011. Pengaruh Kesadaran Wajib pajak dan Sanksi pajak Terhadap Kepatuhan Wajib Pajak Orang Pribadi Pada Kantor Pelayanan Pajak Pratama Palembang Seberang Ulu.

Widayati dan Nurlis. 2010. Faktor-Faktor yang Mempengaruhi Kemauan untuk Membayar Pajak Wajib Pajak Orang Pribadi yang Melakukan Pekerjaan Bebas (Studi Kasus pada KPP Pratama Gambir Tiga). Simposium Nasional Akuntansi XIII. Purwokerto 